\title{
Potensi Antibakteri Ekstrak Tanaman Suku Rubiaceae dan Aplikasinya dalam Sediaan Hand Sanitizer
}

\section{Antibacterial Potential of Rubiaceae Plant Extract and Applications in Hand Sanitizer Preparations}

\author{
Sriwahyuni Iskandar Rasid ${ }^{1}$, Exsyupransia Mursyanti ${ }^{1 *}$, Boy Rahardjo Sidharta ${ }^{1}$ \\ ${ }^{1}$ Prodi Biologi, Fakultas Teknobiologi, Universitas Atma Jaya Yogyakarta \\ Jl. Babarsari No. 44, Sleman, D.I. Yogyakarta, Indonesia \\ Email: e.mursyanti@uajy.ac.id *Penulis Korespondensi
}

\begin{abstract}
Rubiaceae family plants are plants that are widely used as traditional medicine. The content of active compounds in Rubiaceae plants includes alkaloids, flavonoids, saponins, tannins, phenols, and essential oils (anthraquinones) which function as antibacterial compounds. The alcohol content in hand sanitizers, which are marketed in content, gives a feeling of irritation and burning to the skin if used continuously so that the innovation of hand sanitizers from Rubiaceae plants can be used as an alternative for cleaning hands without negative effect for skin. The results of the literature review showed that the Rubiaceae extract and hand sanitizer preparations evaluated for antimicrobials by the agar diffusion method and broth dilution had antibacterial properties against S. aureus and E. coli. Rubiaceae plant hand sanitizer preparations also have physical qualities such as shape, color and odor as well as balance such as pH, viscosity, homogeneity, good adhesion and dispersibility. The good quality category is based on the suitability of SNI related to the stability of the antiseptic gel.
\end{abstract}

Keywords: Antibacterial activity, Hand sanitizer, Rubiaceae family, S. aureus, E. coli

\begin{abstract}
Abstrak
Tanaman suku Rubiaceae merupakan tanaman yang banyak digunakan sebagai obat tradisional. Kandungan senyawa aktif yang ada dalam tanaman suku Rubiaceae meliputi alkaloid, flavonoid, saponin, tanin, fenol, dan minyak atsiri (antrakuinon) yang berpotensi sebagai senyawa antibakteri. Kandungan alkohol dalam hand sanitizer yang beredar di pasaran memberi efek iritasi dan terbakar pada kulit jika digunakan secara terus menerus sehingga perlu inovasi hand sanitizer yang aman tanpa merusak kulit yaitu dari ekstrak tanaman suku Rubiaceae. Beberapa penelitian menunjukkan bahwa ekstrak dan sediaan hand sanitizer tanaman suku Rubiaceae yang diuji aktivitas antimikrobianya dengan metode difusi agar dan broth dilution mempunyai daya antibakteri terhadap $S$. aureus dan E.coli. Sediaan hand sanitizer tanaman suku Rubiaceae juga memiliki kualitas karakteristik fisik seperti bentuk, warna, dan bau serta stabilitas seperti pH, viskositas, homogenitas, daya lekat dan daya sebar yang baik. Kategori kualitas baik ini didasarkan pada kesesuaian SNI terkait kestabilan gel antiseptik.
\end{abstract}

Kata Kunci : Aktivitas antibakteri, Hand sanitizer, Suku Rubiaceae, S. aureus, E. coli

Diterima: 10 Februari 2021, disetujui: 22 Mei 2021

\section{Pendahuluan}

Kondisi aseptis pada tubuh perlu dipertahankan untuk mencegah masuknya mikroorganisme patogen yang kemungkinan besar akan mengakibatkan infeksi. Tangan merupakan bagian tubuh yang sering digunakan untuk melakukan aktivitas sehingga sangat mudah terjadi kontak dengan mikroorganisme penyebab infeksi, salah satunya yaitu mikroorganisme penyebab diare (Pratami et al., 2013). Menurut WHO, penyakit diare merupakan salah satu penyebab utama kematian balita di negara berkembang. Di Indonesia setiap tahun kasus diare sekitar 60 juta kejadian, 70-80\% dari penderita ini adalah balita (Hannif et al., 2011) 
Salah satu cara untuk mencegah penyakit infeksi adalah menggunakan antibiotik namun jika terus menerus dikonsumsi dapat menyebabkan resistensi antibiotik. Oleh karena itu dibutuhkan produk alami karena lebih aman dan tidak memiliki efek samping (Kekuda et al., 2017). Salah satu tanaman yang ekstraknya potensial sebagai antibakteri adalah tanaman suku Rubiaceae. Komponen senyawa kimia dalam tanaman suku ini yang berfungsi sebagai antibakteri adalah flavonoid, saponin, tanin, dan alkaloid (Kesavan et al., 2018).

Salah satu cara pencegahan penyakit diare dan infeksi lain akibat bakteri patogen pada tangan adalah dengan menggunakan hand sanitizer (Miller et al., 2006). Hand sanitizer yang tersebar di pasaran umumnya mengandung alkohol sehingga jika digunakan secara terus-menerus maka dapat menyebabkan kulit menjadi kering, iritasi, bahkan rasa terbakar (Asngad et al., 2018). Umumnya hand sanitizer yang berbentuk gel lebih disukai oleh masyarakat karena rasa dingin di kulit dan mudah mengering (Asngad et al., 2018). $\mathrm{pH}$ hand sanitizer harus diperhatikan karena bila tidak optimal dapat menimbulkan iritasi pada kulit. Menurut SNI No. 06-2588 pH optimal untuk pembuatan hand sanitizer berkisar diantara 4,5-6,5 dan homogenitas untuk sediaan gel adalah yang tidak memiliki butiran kasar maupun gumpalan dalam sediaan tersebut. Daya sebar menurut SNI No. 06-2588 adalah 5-7 cm (Putri et al., 2019). Menurut SNI 16-4399-1996, nilai standar viskositas untuk sediaan gel adalah 2000-50000 Cp (Warnida \& Yullia, 2016).

\section{Manfaat Tanaman Suku Rubiaceae dan kandungan Fitokimianya}

Tanaman suku Rubiaceae merupakan salah satu suku terbesar dari kerajaan tumbuhan yang mempunyai sekitar 13.150 spesies berupa tumbuhan, semak, dan pohon dengan 611 marga yang tersebar di daerah tropis di bumi (Bora et al., 2019). Beberapa jenis tanaman dari suku Rubiaceaei dimanfaatkan sebagai obat tradisional (Tabel $1)$.
Kandungan senyawa aktif yang terdapat pada bagian tanaman suku Rubiaceae baik dari akar, batang, daun, buah dan biji memiliki banyak manfaat. Oleh karena itu, perlu dilakukan skrining fitokimia yang bertujuan untuk mengetahui senyawa metabolit sekunder yang terdapat dalam tanaman Suku Rubiaceae. Banyak penelitian telah melakukan uji metabolit sekunder secara kualitatif dan kuantitatif. Hasil screening fitokimia dari beberapa jenis tanaman suku Rubiaceae secara kualitatif ditampilkan pada Tabel 2.

Kandungan alkaloid pada bagian daun, biji, buah, bunga dan batang tanaman dapat menghambat kerja enzim dalam mensintesis protein bakteri, sehingga metabolisme bakteri terganggu (Oktaviana et al., 2019). Adapun mekanisme kerja flavonoid adalah menghambat fungsi membran sel dan metabolisme energi bakteri (Saptarini et al., 2016). Senyawa fenol dapat mendenaturasi protein dan merusak membran sel bakteri (Saptarini et al., 2016), sedangkan senyawa saponin dapat merusak asam nukleat (DNA dan RNA) bakteri. Aktivitas tanin dapat menginaktivasi adhesin sehingga bakteri tidak dapat menempel pada sel epitel hospes (Toding et al., 2020).

Akar dan daun tanaman suku Rubiaceae mengandung lima antrakuinon dan satu triterpenoid. (Sambou et al., 2017). Antrakuinon bekerja menghambat sintesis protein. Adapun minyak atsiri memiliki kemampuan antibakteri karena pada minyak atsiri terdapat kandungan senyawa terpenoid (Yağız et al., 2017). Adapun Hasil uji kuantitatif kandungan fitokimia pada beberapa jenis tanaman suku Rubiaceae ditampilkan pada Tabel 3.

Hasil uji TPC (Total Phenolic Content) dalam penelitian Ajaib et al., (2018) menunjukkan nilai TPC tertinggi dari ekstrak kulit batang dengan pelarut petroleum eter yaitu sebesar 1,702 $\pm 0,3$ GAE $\mathrm{mg} / \mathrm{mL}$, sementara untuk ekstrak daun pelarut kloroform sebesar 1,11 \pm ,45 GAE $\mathrm{mg} / \mathrm{mL}$. Tingginya kandungan fenolik dalam kulit batang dipengaruhi oleh jenis pelarut, suhu ekstraksi, dan waktu ekstraksi (Sajid et al., 2012). 
Tabel 1. Jenis tanaman Suku Rubiaceae beserta bagian tanaman dan manfaatnya untuk kesehatan

\begin{tabular}{|c|c|c|c|c|}
\hline No & Nama Tanaman & Bagian Tanaman & Manfaat & Referensi \\
\hline \multirow[b]{2}{*}{1} & \multirow[b]{2}{*}{$\begin{array}{c}\text { Kacapiring (Gardenia jasminoides } \\
\text { Ellis) }\end{array}$} & Daun & $\begin{array}{l}\text { Pengobatan nyeri, mimisan, demam, influenza, luka, } \\
\text { mengurangi pembengkakan, mastitis, hepatitis, dan hematuria }\end{array}$ & Kesavan et al., 2018 \\
\hline & & Bunga & $\begin{array}{l}\text { Analgesik, diuretik, larvasida, antihipertensi, antibakteri, } \\
\text { anxiolytic, antiplasmodial, antipiretik, pengobatan sakit } \\
\text { kepala, anti-inflamasi, gangguan hati, konjungtivitis, penyakit } \\
\text { kuning, epistaksis, hematemesis, infeksi piogenik, dan ulkus } \\
\text { kulit }\end{array}$ & Saptarini et al., 2016 \\
\hline 2 & Kacapiring (Gardenia tetrasperma) & Batang, daun, dan biji & Antioksidan, antimikrobia, dan antimalaria & Ajaib et al., 2018 \\
\hline 3 & Kacapiring (Gardenia gummifera) & Daun dan buah & $\begin{array}{l}\text { Wasir, patah tulang, gangguan saraf, penyakit kulit, dan sakit } \\
\text { perut }\end{array}$ & Kekuda et al., 2017 \\
\hline 4 & Kacapiring (Gardenia augusta) & Daun & Antibakteri & Toding et al., 2020 \\
\hline 5 & Mengkudu (Morinda citrifolia L.) & Biji & Antibakteri & Oktaviana et al.,, 2019 \\
\hline 6 & Mengkudu (Morinda geminata DC) & Daun dan akar & $\begin{array}{l}\text { Edema, demam, batuk, malaria, sakit kepala, pengobatan luka, } \\
\text { antiseptik dan hipertensi }\end{array}$ & Sambou et al.,2017 \\
\hline 7 & Kopi Robusta (Coffea robusta L.) & Daging buah & Antioksidan & Harahap, 2018 \\
\hline 8 & Kopi Robusta (Coffea canephora L.) & Daun & $\begin{array}{l}\text { mencegah penyakit degeneratif, menurunkan profil glukosa } \\
\text { darah, tekanan darah dan pengobatan infeksi cacing }\end{array}$ & Muslim dan Dephinto 2019 \\
\hline 9 & Ranggitan (Rubia Tinctorum Linn) & Akar & $\begin{array}{l}\text { diuretik, pengobatan penyakit kuning, linu panggul, } \\
\text { kelumpuhan, pengobatan gangguan rematik dan inflamasi, dan } \\
\text { infeksi kdanung kemih }\end{array}$ & Ghafari et al.,2018 \\
\hline 10 & $\begin{array}{c}\text { Cengkeh (Syzygium aromaticum (L.) } \\
\text { Merr. \& L.M.Perry) }\end{array}$ & Daun & Antibakteri & Fardan dan Harimurti, 2018 \\
\hline 12 & $\begin{array}{l}\text { Galium (Galina incanum, Galim } \\
\text { dieckii dan Galim aladaghensis) }\end{array}$ & Daun & Antioksidan & Yağız et al.,2017 \\
\hline 13 & Soka merah (Ixora coccinea) & Bunga & $\begin{array}{l}\text { Lotion untuk mengobati masalah mata, luka, bisul, astringent } \\
\text { dan antiseptik }\end{array}$ & Nithiyasoundari et al., 2015 \\
\hline 14 & $\begin{array}{l}\text { Semak api/firebush } \\
\text { (Hamelia patens) }\end{array}$ & Daun & Merawat kulit, antimikrobia, antioksidan & Paz et al.,2018 \\
\hline 15 & Bonsai gulgum (Meyna spinosa) & Daun & $\begin{array}{l}\text { Diabetes, difteri, sakit perut, sakit kepala, masalah hati, } \\
\text { gangguan pencernaan, kencing berdenyut, dan masalah kulit } \\
\text { seperti masalah jerawat }\end{array}$ & Bora et al.,2019 \\
\hline
\end{tabular}


Ekstrak daun memiliki nilai TPC dan TFC paling tinggi dibanding bagian tanaman lainnya (Saptarini et al., 2016). Hasil penelitian Anwar et al. (2017) menyatakan bahwa daun mengandung flavonoid dan fenolik tertinggi terutama pada daun dewasa yang mengandung lebih dari $90 \%$ vakuola dalam sel. Berdasarkan data pada Tabel 3 dapat diketahui bahwa pelarut terbaik untuk mengektrak fenol adalah kloroform dan bagian yang memiliki kandungan fenol terbanyak daun (Saptarini et al., 2016). Total Flavonoid Content (TFC) pada G. tetrasperma menunjukkan hasil terbaik pada kulit batang pelarut petroleum eter $(955.1 \pm 1,7 \mathrm{mg} / \mathrm{mL})$ pada konsentrasi $500 \mu \mathrm{L} / \mathrm{mL}$ (Saptarini et al., 2016).

Hasil TFC tertinggi untuk ekstrak daun diperoleh dengan pelarut kloroform (914.4 \pm $0,6 \mathrm{mg} / \mathrm{mL}$ ) pada $1000 \mu \mathrm{L} / \mathrm{mL}$ sedangkan untuk ekstrak biji sebesar $893.7 \pm 0.01 \mathrm{mg} / \mathrm{mL}$ ) pada konsentrasi $1000 \mu \mathrm{L} / \mathrm{mL}$ menggunakan pelarut air (Saptarini et al., 2016). Hal ini dapat disebabkan karena senyawa fenol dan flavonoid terlarut dalam pelarut polar (Suryani et al., 2016)

Tabel 2. Senyawa aktif pada tanaman suku Rubiaceae

\begin{tabular}{|c|c|c|c|c|}
\hline No & Nama Tanaman & $\begin{array}{c}\text { Bagian } \\
\text { Tanaman }\end{array}$ & $\begin{array}{c}\text { Kandungan Senyawa } \\
\text { Aktif }\end{array}$ & Referensi \\
\hline 1 & $\begin{array}{l}\text { Kacapiring (Gardenia jasminoides } \\
\text { Ellis) }\end{array}$ & Daun & $\begin{array}{l}\text { Alkaloid, flavonoid, } \\
\text { saponin, tanin, fenol }\end{array}$ & $\begin{array}{l}\text { Kesavan } \text { et } \\
\text { al.,2018 }\end{array}$ \\
\hline 2 & Kacapiring (G. tetrasperma) & Daun dan Buah & Fenolik & $\begin{array}{c}\text { Kekuda } \text { et } \\
\text { al.,2017 }\end{array}$ \\
\hline 3. & Mengkudu (Morinda citrifolia L.) & Biji & $\begin{array}{c}\text { alkaloid, tanin, } \\
\text { saponin, triterpenoid, } \\
\text { steroid. }\end{array}$ & $\begin{array}{l}\text { Oktaviana et } \\
\text { al.,2019 }\end{array}$ \\
\hline 4 & Kopi robusta (Coffea robusta L.) & Daging Buah & $\begin{array}{l}\text { alkaloid, flavonoid, } \\
\text { terpenoid, dan } \\
\text { polifenol. }\end{array}$ & Harahap, 2018 \\
\hline 5 & Soka merah (Ixora coccinea) & Bunga & $\begin{array}{l}\text { alkaloid, flavonoid, dan } \\
\text { fenol }\end{array}$ & $\begin{array}{c}\text { Nithiyasoundari et } \\
\text { al.,2015 }\end{array}$ \\
\hline 6 & Bonsai gulgum (M. spinosa) & Batang & $\begin{array}{c}\text { alkaloid, terpenoid, } \\
\text { saponin, tanin, } \\
\text { fitosterol, flavonoid, } \\
\text { dan senyawa fenol } \\
\text { alkaloid, terpenoid, } \\
\text { tanin, fitosterol, } \\
\text { flavonoid, dan senyawa } \\
\text { fenol }\end{array}$ & Bora et al.,2019 \\
\hline \multirow[t]{2}{*}{7} & \multirow[t]{2}{*}{ Mengkudu (Morinda geminata DC) } & Daun & $\begin{array}{c}\text { Senyawa antrakuinon } \\
\text { yaitu yaitu } \\
\text { nordamnacanthal, } \\
\text { damnacanthol, lucidin- } \\
\omega \text {-ethyl ether, } \\
\text { antrakuinon, dan asam } \\
\text { ursolat }\end{array}$ & \multirow[t]{2}{*}{$\begin{array}{l}\text { Sambou et al., } \\
2017\end{array}$} \\
\hline & & Akar & antrakuinon & \\
\hline 8 & $\begin{array}{l}\text { Galium (Galina incanum, Galim } \\
\text { dieckii dan Galim aladaghensis) }\end{array}$ & Daun & $\begin{array}{c}\text { monoterpen } \\
\text { monoterpenoid, } \\
\text { sesquiterpene }\end{array}$ & Yağız et al., 2017 \\
\hline
\end{tabular}


Tabel 3. Hasil uji kuantitatif senyawa aktif tanaman suku Rubiaceae

\begin{tabular}{|c|c|c|c|c|c|c|}
\hline No & $\begin{array}{c}\text { Nama } \\
\text { Tanaman }\end{array}$ & $\begin{array}{l}\text { Bagian } \\
\text { tanaman }\end{array}$ & Pelarut & $\begin{array}{c}\text { Senyawa } \\
\text { Aktif }\end{array}$ & $\begin{array}{c}\text { Kadar Senyawa Aktif } \\
(\mathrm{mg} / \mathrm{mL})\end{array}$ & Referensi \\
\hline \multirow[t]{4}{*}{1} & \multirow{4}{*}{$\begin{array}{l}\text { Kacapiring } \\
\text { (Gardenia } \\
\text { jasminoides } \\
\text { Ellis) }\end{array}$} & \multirow{4}{*}{ Daun } & \multirow{4}{*}{$\begin{array}{l}\text { Air dan } \\
\text { alkohol }\end{array}$} & Alkaloid & $2810 \pm 0,31$ & \multirow{4}{*}{$\begin{array}{c}\text { Kesavan et al., } \\
2018\end{array}$} \\
\hline & & & & Flavonoid & $2770 \pm 0,20 \mathrm{GAE}$ & \\
\hline & & & & Phenol & $1910 \pm 0,24 \mathrm{GAE}$ & \\
\hline & & & & Tanin & $1640 \pm 0,13$ & \\
\hline \multirow[t]{10}{*}{2} & \multirow{10}{*}{$\begin{array}{l}\text { Kacapiring } \\
\text { (Gardenia } \\
\text { jasminoides } \\
\text { Ellis) }\end{array}$} & \multirow{5}{*}{ Bunga } & Etanol 96\% & \multirow{10}{*}{$\begin{array}{l}\text { Total } \\
\text { Flavonoid } \\
\text { Content } \\
\text { (TFC) }\end{array}$} & $0,302 \pm 0,0001$ & \multirow{10}{*}{$\begin{array}{l}\text { Saptarini et al., } \\
2016\end{array}$} \\
\hline & & & Etanol: $\mathrm{HCl}$ & & $0,382 \pm 0,0003$ & \\
\hline & & & $\begin{array}{l}\text { Etanol: } \\
\mathrm{H}_{2} \mathrm{SO}_{4}\end{array}$ & & $0,742 \pm 0,0013$ & \\
\hline & & & $\begin{array}{l}\text { Etanol: } \\
\mathrm{HNO}_{3}\end{array}$ & & $0,507 \pm 0,0001$ & \\
\hline & & & $\begin{array}{c}\text { Etanol: } \\
\mathrm{CH}_{3} \mathrm{COOH}\end{array}$ & & $0,785 \pm 0,0011$ & \\
\hline & & \multirow{5}{*}{ Daun } & Etanol 96\% & & $0,897 \pm 0,0001$ & \\
\hline & & & Etanol: $\mathrm{HCl}$ & & $0,292 \pm 0,0001$ & \\
\hline & & & $\begin{array}{l}\text { Etanol: } \\
\mathrm{H}_{2} \mathrm{SO}_{4}\end{array}$ & & $0,452 \pm 0,0006$ & \\
\hline & & & $\begin{array}{l}\text { Etanol: } \\
\mathrm{HNO}_{3}\end{array}$ & & $0,551 \pm 0,0011$ & \\
\hline & & & $\begin{array}{c}\text { Etanol: } \\
\mathrm{CH}_{3} \mathrm{COOH}\end{array}$ & & $0,511 \pm 0,0006$ & \\
\hline \multirow[t]{29}{*}{3} & \multirow{29}{*}{$\begin{array}{l}\text { Kacapiring } \\
(G . \\
\text { tetrasperma) }\end{array}$} & \multirow{4}{*}{$\begin{array}{l}\text { Kulit } \\
\text { batang }\end{array}$} & $\begin{array}{c}\text { Petroleum } \\
\text { eter }\end{array}$ & \multirow{12}{*}{$\begin{array}{l}\text { Total } \\
\text { Phenolic } \\
\text { Content } \\
\text { (TPC) }\end{array}$} & $1,702 \pm 0,3 \mathrm{GAE}$ & \multirow{29}{*}{$\begin{array}{l}\text { Ajaib et al., } \\
2018\end{array}$} \\
\hline & & & kloroform & & $0,63 \pm 0,1 \mathrm{GAE}$ & \\
\hline & & & Metanol & & $1,43 \pm 6 \mathrm{GAE}$ & \\
\hline & & & Aquades & & $0,4 \pm 1,4 \mathrm{GAE}$ & \\
\hline & & \multirow{4}{*}{ Daun } & $\begin{array}{c}\text { Petroleum } \\
\text { eter }\end{array}$ & & $0,71 \pm 0,7 \mathrm{GAE}$ & \\
\hline & & & kloroform & & $1,11 \pm 0,45 \mathrm{GAE}$ & \\
\hline & & & Metanol & & $0,84 \pm 2,4 \mathrm{GAE}$ & \\
\hline & & & Aquades & & $0,56 \pm 0,9 \mathrm{GAE}$ & \\
\hline & & \multirow{4}{*}{ Biji } & $\begin{array}{l}\text { Petroleum } \\
\text { eter }\end{array}$ & & $0,8 \pm 1,7 \mathrm{GAE}$ & \\
\hline & & & kloroform & & $0,95 \pm 2,3 \mathrm{GAE}$ & \\
\hline & & & Metanol & & $1,032 \pm 0,1 \mathrm{GAE}$ & \\
\hline & & & Aquades & & $1,07 \pm 3,7 \mathrm{GAE}$ & \\
\hline & & \multirow{17}{*}{$\begin{array}{c}\text { Kulit } \\
\text { batang }\end{array}$} & \multirow{4}{*}{$\begin{array}{l}\text { Petroleum } \\
\text { eter }\end{array}$} & & $1000 \mu \mathrm{L}: 676.6 \pm 1.5$ & \\
\hline & & & & & $500 \mu \mathrm{L}: 955.1 \pm 1.7$ & \\
\hline & & & & & $250 \mu \mathrm{L}: 893.7 \pm 0.5$ & \\
\hline & & & & & $125 \mu \mathrm{L}: 515.6 \pm 0.4$ & \\
\hline & & & \multirow{4}{*}{ kloroform } & & $1000 \mu \mathrm{L}: 802.2 \pm 1.04$ & \\
\hline & & & & & $500 \mu \mathrm{L}: 701.1 \pm 0.3$ & \\
\hline & & & & & $250 \mu \mathrm{L}: 902.1 \pm 0.5$ & \\
\hline & & & & & $125 \mu \mathrm{L}: 661.3 \pm 0.5$ & \\
\hline & & & & & $1000 \mu \mathrm{L}: 598.6 \pm 0.9$ & \\
\hline & & & Motom & & $500 \mu \mathrm{L}: 626.7 \pm 0.4$ & \\
\hline & & & Metanol & & $250 \mu \mathrm{L}: 702.4 \pm 0.4$ & \\
\hline & & & & & $125 \mu \mathrm{L}: 402.5 \pm 0.7$ & \\
\hline & & & & & $1000 \mu \mathrm{L}: 794 \pm 1.1$ & \\
\hline & & & & & $500 \mu \mathrm{L}: 682.9 \pm 0.4$ & \\
\hline & & & Aquades & & $250 \mu \mathrm{L}: 498 \pm 2.7$ & \\
\hline & & & & & $125 \mu \mathrm{L}: 431.9 \pm 0.99$ & \\
\hline & & & & & BHT standar :913.5 & \\
\hline
\end{tabular}




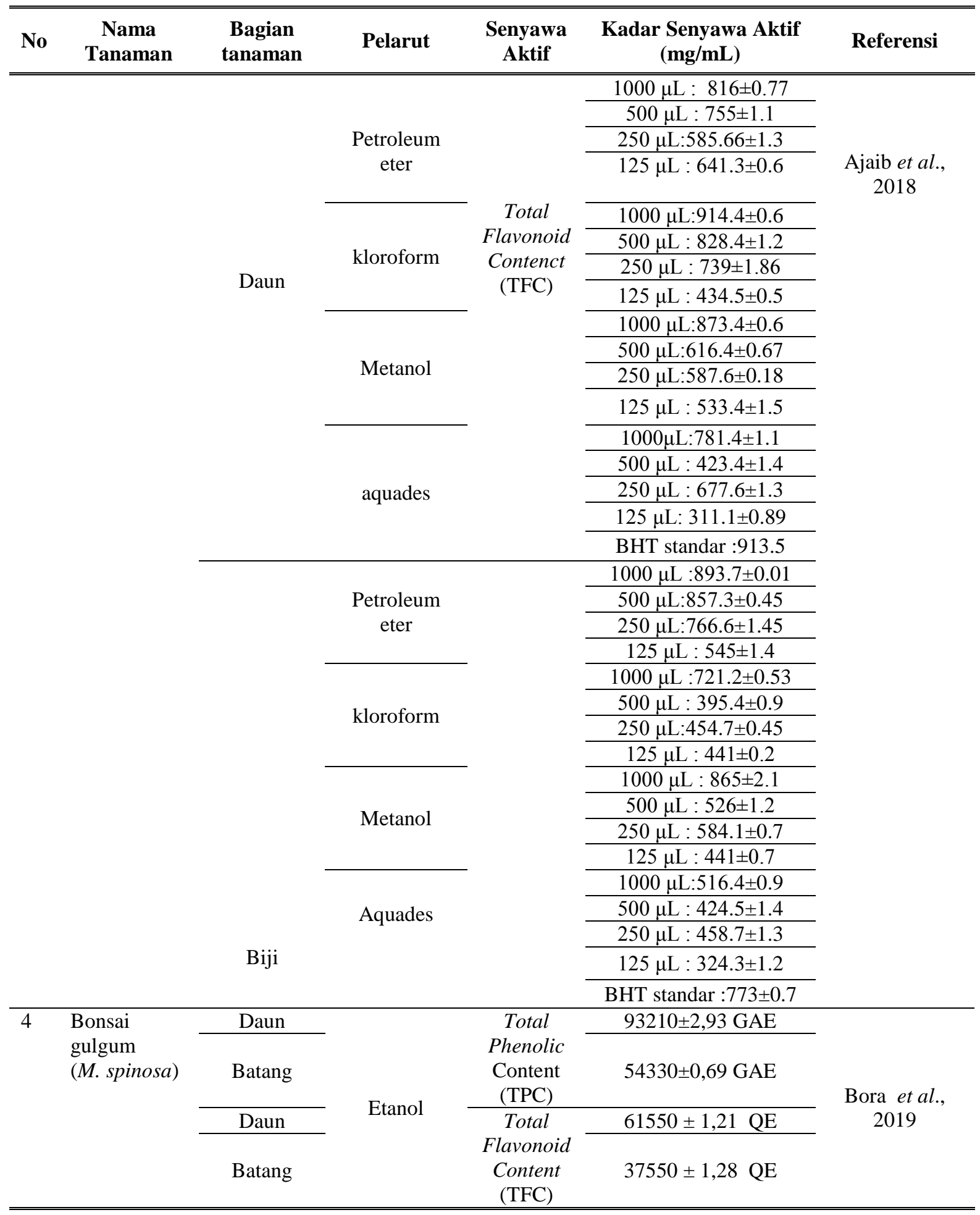

\section{Aktivitas Antibakteri Ekstrak Tanaman Suku Rubiaceae}

Uji aktivitas antibakteri ekstrak bagian tanaman suku Rubiaceae dilakukan dengan metode difusi sumuran untuk melihat luas zona hambat dan metode dilusi untuk menentukan nilai Konsentrasi Hambat Minimum (KHM).
Aktivitas antibakteri ditentukan dari luas zona hambat yang terbentuk yang ditandai dengan diameter zona jernih yang dihasilkan (Kusmiyati dan Agustini, 2007). Konsentrasi Hambat Minimum (KHM) adalah konsentrasi terendah yang masih dapat menghambat pertumbuhan mikroorganisme tertentu (Kusmiyati dan Agustini 2007). Hasil uji 
aktivitas antibakteri beberapa jenis tanaman suku Rubiaceae ditampilkan pada Tabel 4.

Data hasil uji aktivitas antibakteri pada Tabel 4 menunjukkan bahwa daya hambat tanaman Suku Rubiaceae terhadap bakteri Gram positif lebih tinggi daripada bakteri Gram negatif. Hal ini dapat disebabkan karena perbedaan struktur dinding sel bakteri (Kekuda et al., 2017). Selain itu semakin tinggi konsentrasi ekstrak yang digunakan maka semakin besar luas zona hambat ekstrak terhadap bakteri uji (Suriawiria, 2005).

Pelarut terbaik untuk mengekstrak zat aktif adalah metanol. Metanol memiliki gugus polar yang lebih kuat daripada gugus nonpolar, hal ini dapat terlihat dari struktur kimia metanol yang mengandung gugus hidroksil (polar) dan gugus karbon (nonpolar) (Ukhty, 2011). Menurut Sjahid (2008) flavonoid adalah golongan fenol yang merupakan senyawa polar karena mempunyai sejumlah gugus hidroksil yang tak tersulih atau suatu gula, sehingga akan larut dalam pelarut polar seperti metanol.

Nilai KHM umumnya dievaluasi menggunakan Broth dilution. MBC (Minimum Bactericidal Concentration) atau KBM (Kadar Bunuh Minimum) juga diuji. Media agar yang menunjukkan visualisasi kejernihan dan tidak ditumbuhi bakteri ditetapkan sebagai konsentrasi bunuh minimum (KBM), berbeda dengan MIC (Minimum Inhibitory Concentration) atau KHM di mana pengamatan secara visual dilakukan dengan melihat perbedaan kejernihan sumur yang dibandingkan dengan kontrol (Kurniati et al., 2017). Hasil uji KHM pada beberapa tanaman suku Rubiaceae ditampilkan pada Tabel 5.

Berdasarkan data pada Tabel 5, nilai KHM terbaik diperoleh dari akar tanaman Ranggitan (Rubia Tinctorum Linn.) dengan konsentrasi hambat bakteri yang terendah (Ghafari et al., 2018). Hal ini dapat disebabkan karena pemilihan pelarut yang tepat saat mengesktrak akar ranggitan yaitu menggunakan metanol.

Metanol merupakan pelarut polar. Metanol memiliki gugus polar yang lebih kuat daripada gugus nonpolar, hal ini dapat terlihat dari struktur kimia metanol yang mengandung gugus hidroksil (polar) dan gugus karbon (nonpolar) (Ukhty, 2011). MBC juga diuji pada salah satu tanaman suku Rubiaceae yaitu daun Hamelia patens dengan hasil MBC terendah pada metode perkolasi dengan pelarut etanol $70 \%$ yaitu sebesar $3,5 \mathrm{mg} / \mathrm{mL}$ terhadap S. aureus dan E. coli (Paz et al., 2018).

\section{Aplikasi ekstrak Tanaman Suku Rubiaceae sebagai Hand Sanitizer untuk Antibakteri Alami}

Hasil uji organoleptik yang meliputi bau, warna, bentuk, viskositas, homogenitas, daya lekat, daya sebar dan $\mathrm{pH}$ serta aktivitas antibakteri ekstrak tanaman suku Rubiaceae sediaan gel hand sanitizer dari beberapa penelitian ditampilkan pada Tabel 6.

Data aktivitas antibakteri ekstrak tanaman suku Rubiaceae dalam sediaan gel hand sanitizer pada Tabel 6 menunjukkan bahwa aktivitas antibakteri sediaan hand sanitizer tanaman Rubiaceae tertinggi yaitu oleh buah Randia spinosa yang diformulasikan menggunakan carbomer 934 (Tilloo et al., 2012). Carbopol 934 adalah golongan karbomer yang stabil (Rowe et al., 2009).

Kekentalan karbomer dapat terjamin selama penyimpanan dalam jangka waktu yang lama pada temperatur ruangan (Rowe et al., 2009). Penelitian Tilloo et al. (2012) menyatakan bahwa buah Randia spinosa yang diformulasikan dengan Carbopol 934 (1,5\%) menunjukkan hasil luas zona hambat sebesar $22 \mathrm{~mm}$, pembanding gel sebesar $18 \mathrm{~mm}$, dan kontrol positif (ciprofloxacin) sebesar $22 \mathrm{~mm}$ terhadap S. aureus. 
Tabel 4. Aktivitas antibakteri tanaman suku Rubiaceae

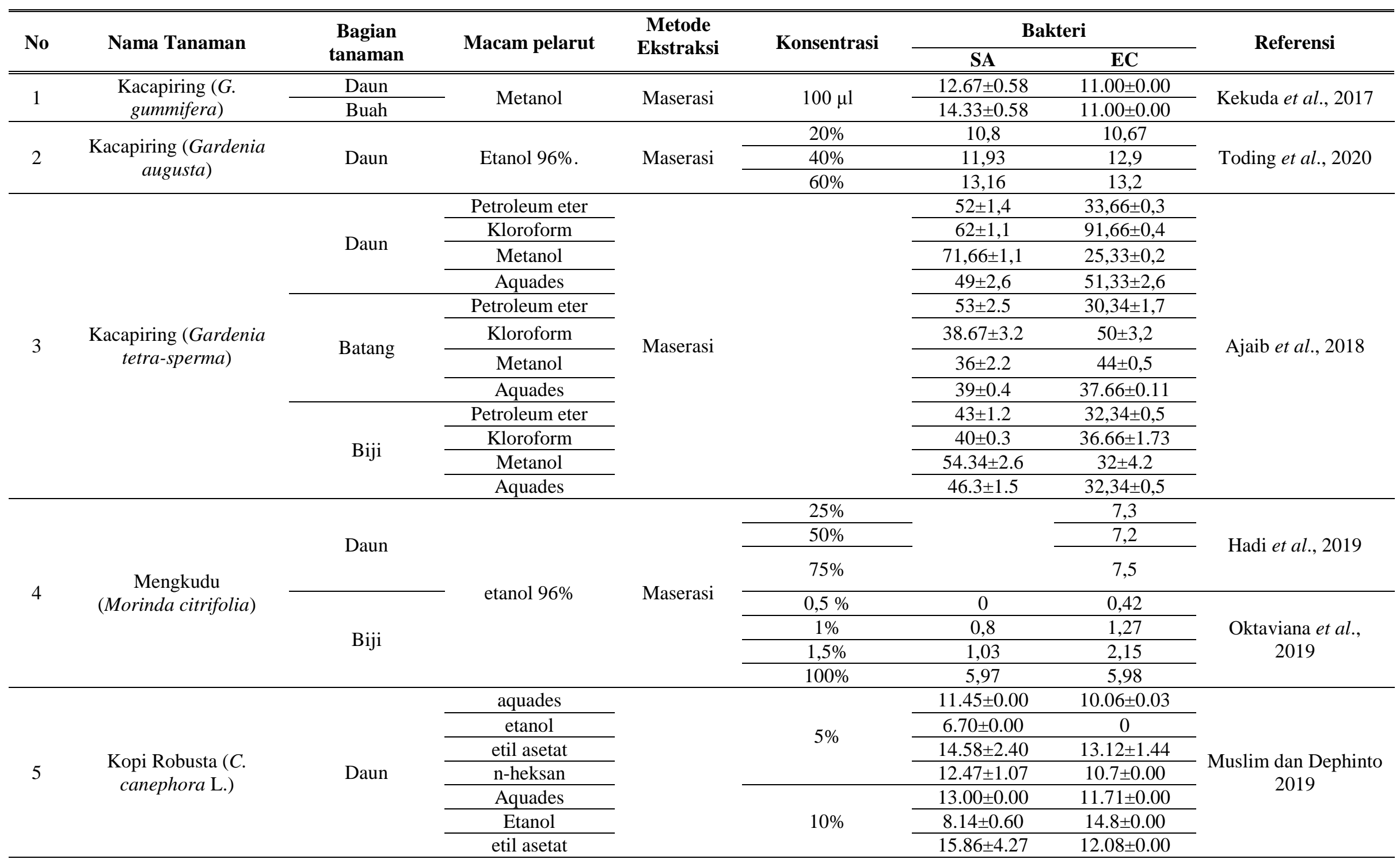




\begin{tabular}{|c|c|c|c|c|c|c|c|c|}
\hline & & & n-heksan & & & $11.51 \pm 0.83$ & $12.07 \pm 0.53$ & \\
\hline & & & Aquades & & \multirow{4}{*}{$15 \%$} & $12.51 \pm 1.00$ & $11.15 \pm 1.00$ & \\
\hline & & & Etanol & & & $9.29 \pm 0.06$ & $15.27 \pm 0.06$ & \\
\hline & & & etil asetat & & & $18.58 \pm 1.15$ & $17.28 \pm 1.15$ & \\
\hline & & & n-heksan & & & $13.52 \pm 0.00$ & $13.31 \pm 0.00$ & \\
\hline \multirow{3}{*}{6} & \multirow{3}{*}{$\begin{array}{l}\text { Daun } \\
\text { Galium }\end{array}$} & $\begin{array}{l}\text { Galinaa } \\
\text { incanum }\end{array}$ & & \multirow{2}{*}{$\begin{array}{l}\text { Hydro- } \\
\text { distillation }\end{array}$} & & $7 \pm 0.5$ & $9.8 \pm 0.6$ & \multirow{3}{*}{ Yağız et al., 2017} \\
\hline & & Galim dieckii & & & $15 \mathrm{mg} / \mathrm{mL}$ & $9.1 \pm 0.7$ & $9.3 \pm 0.7$ & \\
\hline & & $\begin{array}{c}\text { Galim } \\
\text { aladaghense }\end{array}$ & & $\begin{array}{c}\text { Hydro- } \\
\text { distillation }\end{array}$ & & $10 \pm 0.6$ & $11.5 \pm 0.8$ & \\
\hline \multirow{3}{*}{7} & \multirow{3}{*}{$\begin{array}{c}\text { Ranggitan } \\
\text { (Rubia Tinctorum) }\end{array}$} & \multirow{3}{*}{ Akar } & \multirow{3}{*}{ metanol } & \multirow{3}{*}{ Maserasi } & $50 \mu \mathrm{l}$ & $10.3 \pm 0.57$ & $15 \pm 0.0$ & \multirow{3}{*}{ Ghafari et al., 2018} \\
\hline & & & & & $75 \mu \mathrm{l}$ & $14.3 \pm 0.57$ & $15 \pm 0.0$ & \\
\hline & & & & & $100 \mu \mathrm{l}$ & $15 \pm 0.0$ & $17.3 \pm 0.57$ & \\
\hline \multirow{7}{*}{8} & \multirow{7}{*}{ Soka (Ixora coccinea $\mathrm{L}$ ) } & \multirow{7}{*}{ Bunga } & \multirow{3}{*}{ Etanol 70\% } & \multirow{3}{*}{ Maserasi } & $50 \%$ & $10,67 \pm 1,366$ & $7,50 \pm 3,834$ & \multirow{3}{*}{$\begin{array}{l}\text { Hendra dan Yuni } \\
2016\end{array}$} \\
\hline & & & & & $75 \%$ & $10,33 \pm 1,862$ & $7,83 \pm 4,355$ & \\
\hline & & & & & $100 \%$ & $14,50 \pm 2,074$ & $11,00 \pm 5,081$ & \\
\hline & & & \multirow{2}{*}{ Metanol } & & $75 \mu \mathrm{l}$ & 17 & 12 & \multirow{4}{*}{$\begin{array}{c}\text { Nithiyasoundari et } \\
\text { al., } 2015\end{array}$} \\
\hline & & & & Soxhlet & $100 \mu \mathrm{l}$ & 21 & 19 & \\
\hline & & & \multirow{2}{*}{ Aquades } & soxniet & $75 \mu \mathrm{l}$ & 8 & 10 & \\
\hline & & & & & $100 \mu \mathrm{l}$ & 11 & 13 & \\
\hline \multirow{3}{*}{9} & \multirow{3}{*}{$\begin{array}{c}\text { Kopi robusta (Coffea } \\
\text { robusta } \mathrm{L} .\end{array}$} & \multirow{3}{*}{ Daging buah } & \multirow{3}{*}{ Metanol } & \multirow{3}{*}{ Maserasi } & $1 \%$ & 15,1 & 6,5 & \multirow{3}{*}{ Harahap, 2018} \\
\hline & & & & & $2 \%$ & 1 & 7,2 & \\
\hline & & & & & $3 \%$ & 15,3 & 7,8 & \\
\hline \multirow{3}{*}{10} & \multirow{3}{*}{$\begin{array}{c}\text { Balik angin } \\
\text { (Mussaenda frondosa } \\
\text { L.) }\end{array}$} & \multirow{3}{*}{ Bunga } & Etil asetat & & & $6,0 \pm 0$ & & \\
\hline & & & n-heksana & Maserasi & & $7,5 \pm 4$ & & Efendi, 2019 \\
\hline & & & n-butanol & & & $7,5 \pm 4$ & & \\
\hline & & & & & nordamnacanthal & 14 & 0 & \\
\hline & & & & & damnacanthol & 16 & 0 & \\
\hline 11 & Mengkudu (Morinda & & CyH, etil asetat, & & lucidin- $\omega$-ethyl & 9 & 0 & \\
\hline 11 & geminata $\mathrm{DC})$ & AKar dan Daun & ethanol, dan & Maserası & eter & 10 & 0 & Sambou et al., 2017 \\
\hline & & & & & antrakuinon & 10 & 13 & \\
\hline & & & & & asam ursolat & 13 & 0 & \\
\hline 12 & $\begin{array}{l}\text { Bonsai gulo gumantum } \\
\text { (Randia spinosa) }\end{array}$ & Buah & Petroleum eter & & & 21,3 & & Tilloo et al., 2012 \\
\hline
\end{tabular}

Keterangan: EC: Escherichia coli; SA: Staphylococcus aureus 
Tabel 5. Nilai Konsentrasi Hambat Minimum (KHM) tanaman suku Rubiaceae

\begin{tabular}{|c|c|c|c|c|c|c|c|c|c|}
\hline No & Tanaman & $\mathbf{B a}$ & an tanaman & Bakteri uji & Pelarut & KHM (mg/mL) & MBC & $\begin{array}{l}\text { Metode } \\
\text { Maserasi }\end{array}$ & Referensi \\
\hline \multirow{6}{*}{1} & \multirow{6}{*}{$\begin{array}{c}\text { Kacapiring } \\
\text { (Gardenia tetrasperma) }\end{array}$} & \multirow{2}{*}{\multicolumn{2}{|c|}{ Daun }} & EC & \multirow{6}{*}{$\begin{array}{l}\text { petroleum eter, } \\
\text { kloroform, } \\
\text { metanol dan air } \\
\text { suling }\end{array}$} & 0,8 & & \multirow{6}{*}{ Maserasi } & \multirow{6}{*}{$\begin{array}{l}\text { Ajaib et al., } \\
\quad 2018\end{array}$} \\
\hline & & & & SA & & 0,9 & & & \\
\hline & & \multirow{2}{*}{\multicolumn{2}{|c|}{ Batang }} & $\mathrm{EC}$ & & 0,7 & & & \\
\hline & & & & SA & & 1 & & & \\
\hline & & \multirow{2}{*}{\multicolumn{2}{|c|}{ Biji }} & $\mathrm{EC}$ & & 0,4 & & & \\
\hline & & & & SA & & 0,9 & & & \\
\hline \multirow{12}{*}{2} & \multirow{12}{*}{$\begin{array}{c}\text { Mengkudu } \\
\text { (Morinda geminata DC) }\end{array}$} & \multirow{12}{*}{$\begin{array}{l}\text { Akar dan } \\
\text { Daun }\end{array}$} & Nordamna-canthal & & & 0 & & \multirow{12}{*}{ Maserasi } & \multirow{12}{*}{$\begin{array}{l}\text { Sambou } \text { et } \\
\text { al., } 2017\end{array}$} \\
\hline & & & Damnacan-thol & & & 0 & & & \\
\hline & & & lucidin- $\omega$-ethyl & & & - & & & \\
\hline & & & eter & $\mathrm{EC}$ & & 0 & & & \\
\hline & & & antrakuinon & & & 0,625 & & & \\
\hline & & & asam ursolat & & & 0 & & & \\
\hline & & & Nordamna-canthal & \multirow{6}{*}{ SA } & & 0,156 & & & \\
\hline & & & Damnacan-thol & & & 0,312 & & & \\
\hline & & & lucidin- $\omega$-ethyl & & & - & & & \\
\hline & & & eter & & & 0,156 & & & \\
\hline & & & antrakuinon & & & 0,625 & & & \\
\hline & & & asam ursolat & & & 1,25 & & & \\
\hline \multirow{8}{*}{3} & \multirow{8}{*}{$\begin{array}{c}\text { Kopi Robusta ( } C \text {. } \\
\text { canephora } \mathrm{L} .\end{array}$} & \multirow{8}{*}{\multicolumn{2}{|c|}{ Daun }} & \multirow{4}{*}{$\mathrm{EC}$} & fraksi air & 50 & & & \multirow{8}{*}{$\begin{array}{c}\text { Muslim dan } \\
\text { Dephinto } \\
2019\end{array}$} \\
\hline & & & & & etanol & 100 & & & \\
\hline & & & & & etil asetat & 50 & & & \\
\hline & & & & & n-heksan & 50 & & & \\
\hline & & & & \multirow{4}{*}{ SA } & fraksi air & 50 & & & \\
\hline & & & & & etanol & 100 & & & \\
\hline & & & & & etil asetat & 50 & & & \\
\hline & & & & & n-heksan & 50 & & & \\
\hline \multirow{6}{*}{4} & \multirow{6}{*}{$\begin{array}{l}\text { Ranggitan (Rubia } \\
\text { Tinctorum Linn.) }\end{array}$} & \multirow{6}{*}{\multicolumn{2}{|c|}{ Akar }} & $\mathrm{EC}$ & Petroleum eter & 1.25 & & \multirow{6}{*}{ Maserasi } & \multirow{6}{*}{$\begin{array}{l}\text { Ghafari et } \\
\text { al., } 2018\end{array}$} \\
\hline & & & & SA & Petroleum eter & 0.625 & & & \\
\hline & & & & $\mathrm{EC}$ & & 0.3125 & & & \\
\hline & & & & SA & Metanol & 0.1562 & & & \\
\hline & & & & $\mathrm{EC}$ & \multirow{2}{*}{ kloroform } & 2,5 & & & \\
\hline & & & & SA & & - & & & \\
\hline 5 & Galium & & na incanum & SA & n-heksana & $2.4 \pm 0.04$ & & Hydro- & Yağız et al., \\
\hline
\end{tabular}




\begin{tabular}{|c|c|c|c|c|c|c|c|c|}
\hline No & Tanaman & Bagian tanaman & Bakteri uji & Pelarut & KHM (mg/mL) & MBC & $\begin{array}{c}\text { Metode } \\
\text { Maserasi }\end{array}$ & Referensi \\
\hline & & Galim dieckii & & & $1.6 \pm 0.02$ & & \multirow[t]{5}{*}{ distillation } & \multirow[t]{5}{*}{2017} \\
\hline & & Galim aladag-hensi & & & $1.2 \pm 0.02$ & & & \\
\hline & & Galina incanum & \multirow{3}{*}{$\mathrm{EC}$} & & $0.4 \pm 0.02$ & & & \\
\hline & & Galim dieckii & & & $0.4 \pm 0.02$ & & & \\
\hline & & Galim aladag-hensi & & & $0.8 \pm 0.02$ & & & \\
\hline \multirow{6}{*}{6.} & \multirow{6}{*}{$\begin{array}{l}\text { Semak api/firebush } \\
\text { (Hamelia patens) }\end{array}$} & \multirow{6}{*}{ Daun } & $\mathrm{EC}$ & \multirow{6}{*}{ Etanol 70\% } & 4 & & \multirow{2}{*}{ Maserasi } & \multirow{6}{*}{$\begin{array}{l}\text { Paz et al., } \\
\quad 2018\end{array}$} \\
\hline & & & SA & & 12 & & & \\
\hline & & & $\mathrm{EC}$ & & 7,5 & & \multirow{2}{*}{ Sokhlet } & \\
\hline & & & SA & & 8 & & & \\
\hline & & & $\mathrm{EC}$ & & 3,5 & & \multirow{2}{*}{ Perkolasi } & \\
\hline & & & SA & & 3,5 & & & \\
\hline
\end{tabular}

Keterangan: EC: Escherichia coli; SA: Staphylococcus aureus 
Tabel 6. Uji oganoleptik dan aktivitas antibakteri ekstrak tanaman suku Rubiaceae

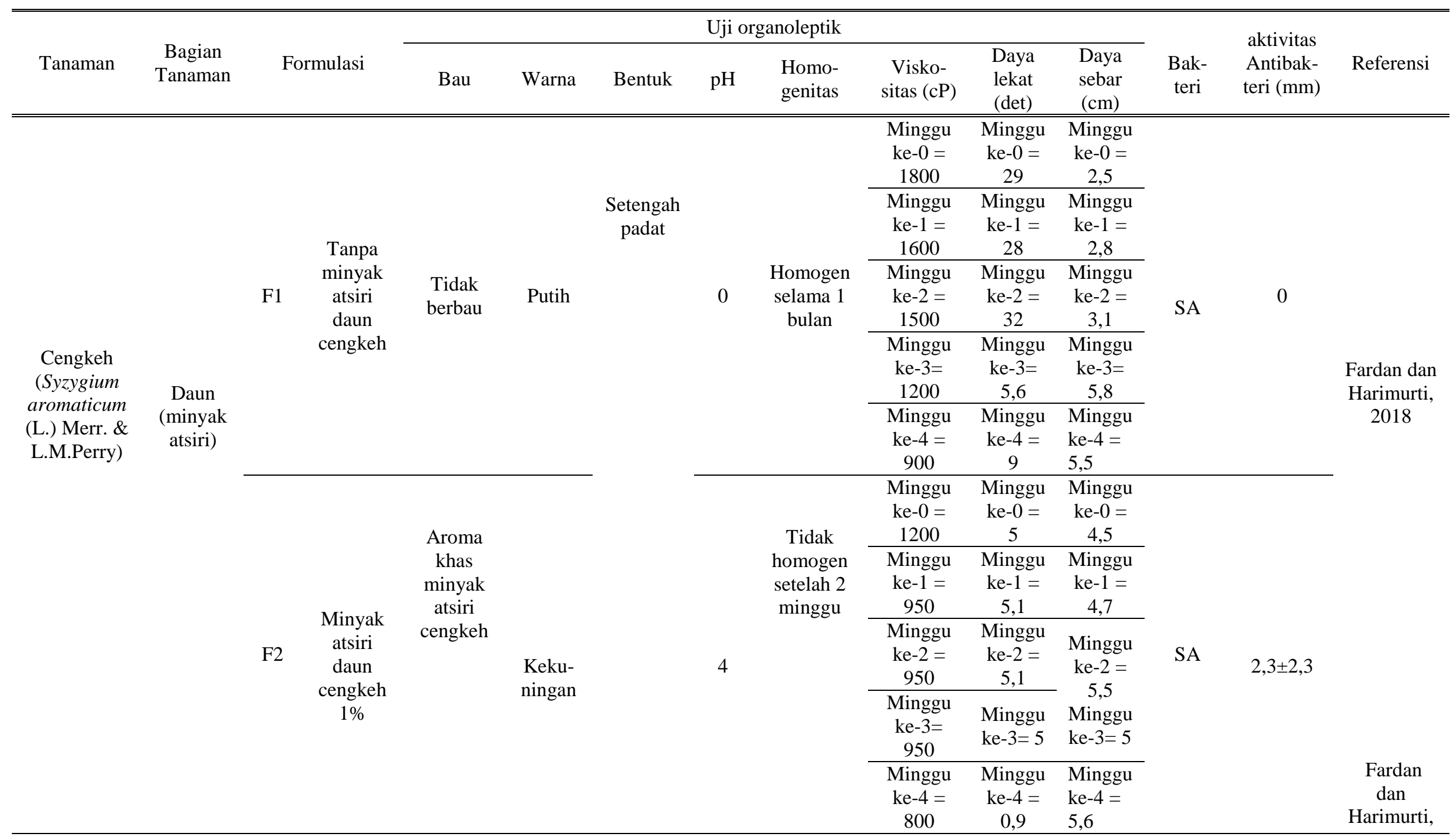




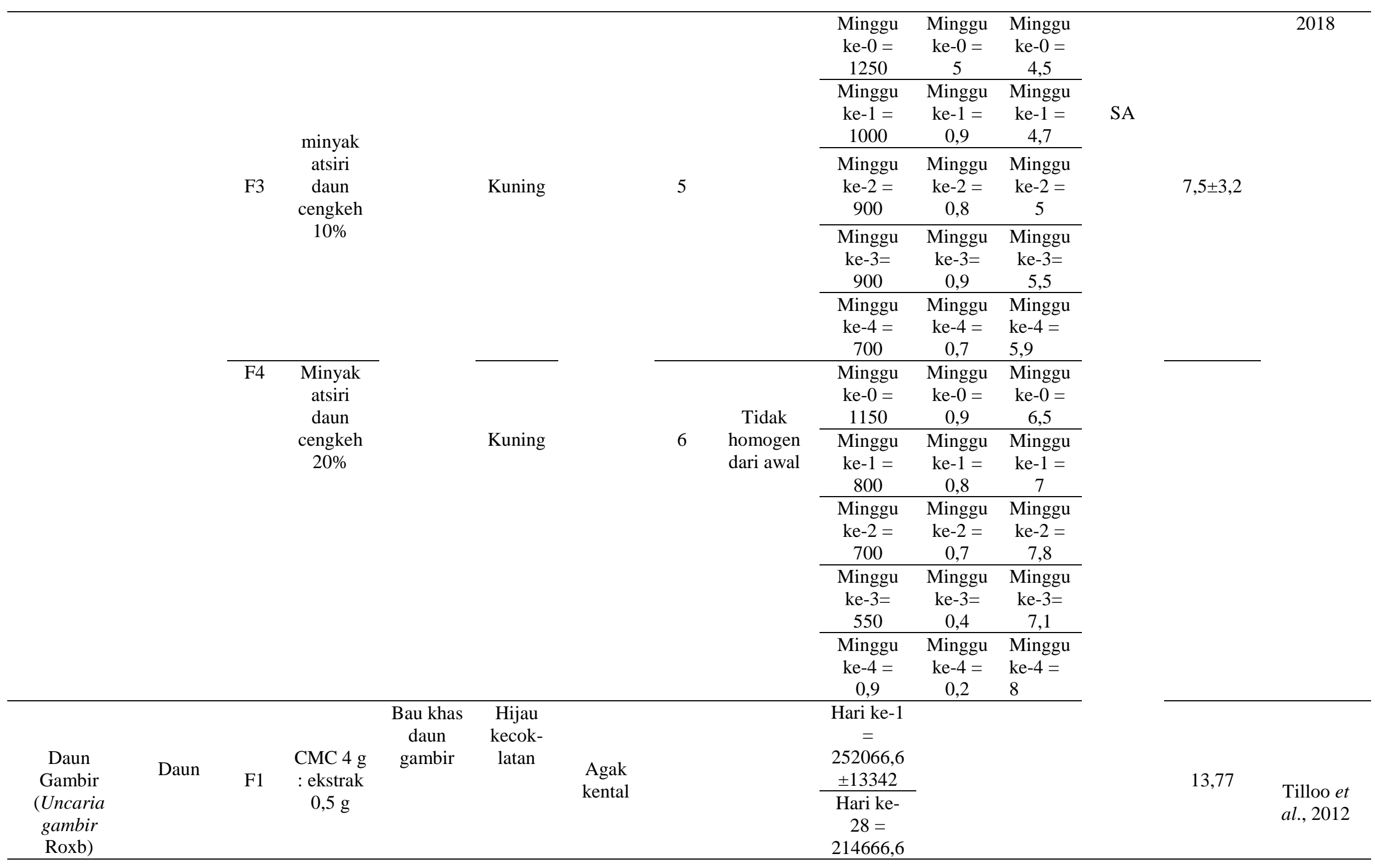




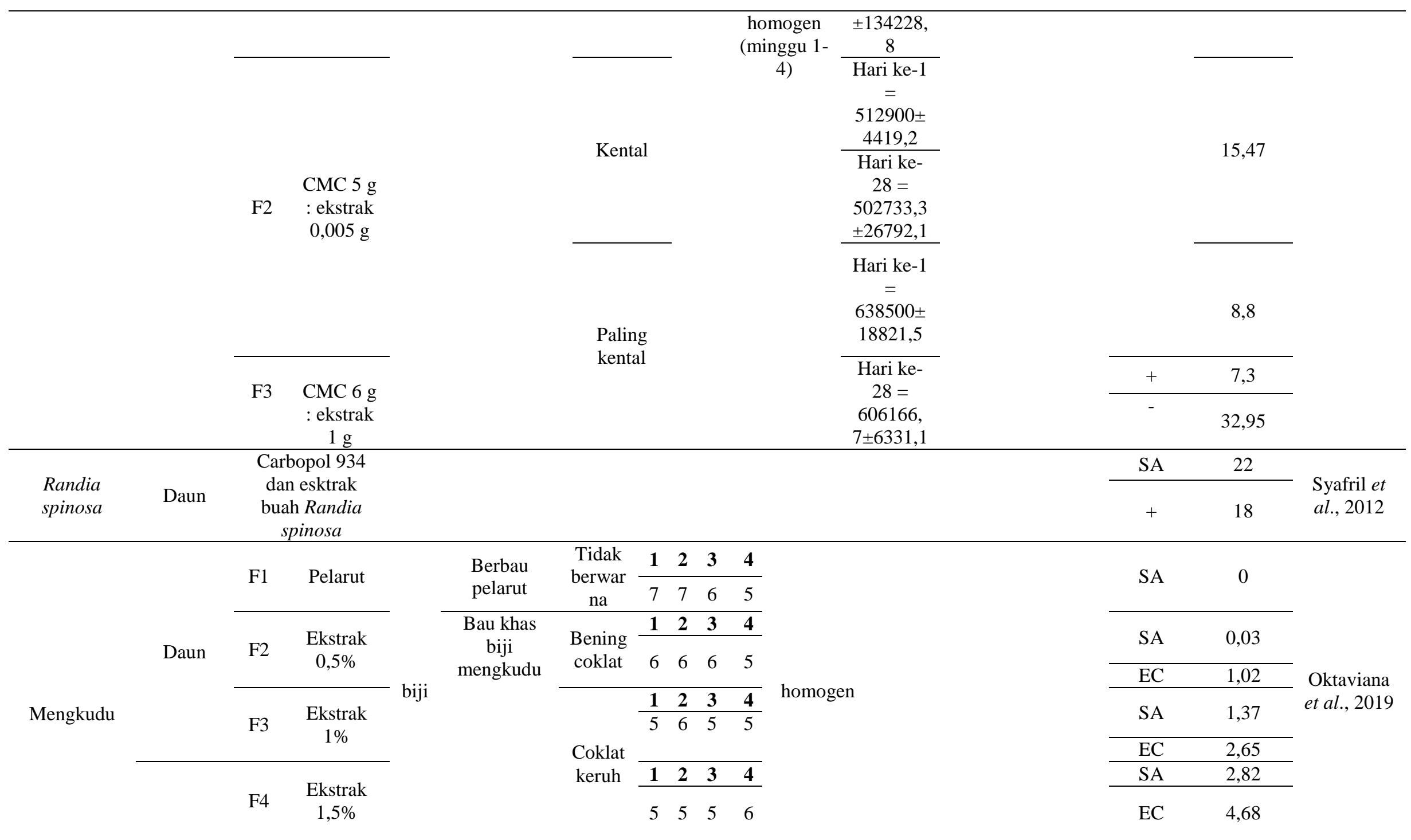

Keterangan : SA : Staphylococcus aureus; EC : Escherichia coli ; + : kontrol positif; - : kontrol negatif 


\section{Simpulan}

Tanaman suku Rubiaceae mengandung senyawa flavonoid, tanin, saponin, dan alkaloid yang memiliki aktivitas antibakteri terhadap $S$. aureus dan E. coli. Ekstrak bagian tanaman suku Rubiaceae yang optimal dalam menghambat $S$. aureus dan E. coli dilihat dari nilai Luas Zona Hambat (LZH) adalah bagian akar dengan pelarut terbaik yaitu metanol. Sediaan gel hand sanitizer dari ektrak tanaman suku Rubiaceae juga efektif sebagai antibakteri untuk $S$. aureus dan E. coli. Hasil uji karakteristik fisik dan stabilitas gel meliputi bentuk, warna, $\mathrm{pH}$, daya sebar, homogenitas, dan viskositas menunjukkan kualitas yang baik sesuai SNI.

\section{Daftar Pustaka}

Ajaib, M. Latif, S.A. Mirza, Hassan, A. U., Iqbal, M. A., dan Khan, Z. (2018). Antimicrobial and antioxidant screening of Gardenia Tetrasperma. Pakistan Journal of Science 70 (3): 93-98.

Anwar, K., Rahmanto, B., Triyasmono, L., Rizki, M. I., Halwany, W., dan Lestari, F. (2017). The influence of leaf age on total phenolic, flavonoids, and free radical scavenging capacity of Aquilaria beccariana. Research Journal of Pharmaceutical, Biological and Chemical Sciences 2017(129); 129-133.

Asngad, A., Bagas, A., dan Nopitasari. (2018). Kualitas gel pembersih tangan (Handsanitizer) dari ekstrak batang pisang dengan penambahn alkohol, triklosan dan gliserin yang berbeda dosisnya. Bioeksperimen 4 (2): 61-70

Bora, R., Khakhalary, S. dan Dutta, T. (2019). Phytochemical profiling, assessment of total phenolic content, total flavonoid content, and antioxidant activity of ethnomedicinal plant, Meyna spinosa from assam. Asian Journal of Pharmaceutical and Clinical Research 12 (11): 61-63.

Efendi, R. M. 2019. Skrining aktivitas antibakteri fraksi kelopak bunga Mussaenda frondosa L. (2019). Journal of Pharmaceutical and sciences 2 (1): 38-44.

Fardan, I dan Harimurti, S. (2018). Formulasi sediaan gel minyak atsiri daun cengkeh (Syzygium aromaticum (L.) Merr. \& L.M.Perry) sebagai antiseptik tangan dan uji daya hambat terhadap bakteri Staphylococcus aureus. PHARMACY (Pharmaceutical Journal of Indonesia): Jurnal Farmasi Indonesia 7 (1): 710-716

Ghafari, R., Mouslemanie, N. dan Nayal, R. (2018). Antibacterial activity of Rubia Tinctorum Linn. root extracts. International Journal Pharmaceutical Science and Research 9 (9): 3914-3918.

Hadi, D. K., Erina, Rinidar, Fakrurrazi, Rosmaidar, dan Sayuthi, A. (2019). Daya Hambat Ekstrak Etanol Daun Mengkudu (Morinda citrifolia L.) terhadap Pertumbuhan Salmonella sp. dan Escherichia coli. Jimvet 3(2): 87-97.

Hannif., Mulyani, S. dan Kuschitawaty. (2011). Faktor risiko diare akut pada balita. Jurnal Berita Kedokteran Masyarakat 27: 10-17

Harahap, M. R. (2018). Aktivitas daya hambat limbah daging buah kopi robusta ( Coffea robusta L.) Aceh terhadap Bakteri S.aureus dan E.coli. Jurnal Kesehatan, 9(1): 93.

Kekuda, P., Raghavendra., Shilpa., Pushpavathi., Petkar, T., dan Siddiqha, A. (2017). Antimicrobial, antiradical, and insectidical activity of Gardenia gummifera L. F. (Rubiaceae). International Journal of Pharmacy and Pharmaceutical Sciences 9 (10): 265-272.

Kurniati, N. F., Garmana, A. N. dan Aziz, N. (2017). Aktivitas antibakteri dan antijamur ekstrak etanol akar, bunga, dan daun turi (Serbania grandifloraL. Poir. Acta Pharmaceutical Indonesia 1(42): 1-8.

Kesavan, K., Gnanasekaran, J., Gurunagarajan, S., Nayagam, A. A. J. (2018). Microscopic, physicochemical and phytochemical analysis of Gardenia jasminoides (Ellis). International Journal of Pharmacy and Pharmaceutical Sciences 10 (1): 97-102.

Kusmiyati, K., dan Agustini, N. W. S. (2007). Uji Aktivitas Senyawa Antibakteri dari Mikroalga Porphyridium cruentum. Biodiversitas, 8, 48-53.

Miller., Michael, A. (2006). Does the clinical use of ethanol-based hand sanitizer elevate blood alcohol levels? A prospective study. The American Journal of Emergency Medicine. Vol 24 (7): 815-817

Muslim, Z dan Dephinto, Y. (2019). Antibacterial activity of robusta coffee (Coffea canephora 1.) leaves to Staphylococcus aureus and Escherichia coli. Asian Journal of 
Pharmaceutical and Clinical Research 12 (12): 113-115.

Nithiyasoundari, M., Parimala, K.S., Balaji, S. (2015).Efficacy of Ixora coccinea against common fish pathogens. International Journal of Research Ayurveda Pharmacy (IJRAP). 6 (4): 489-492.

Oktaviana, S., Mursiti, S. dan Wijayati, N. (2019). Uji aktivitas antibakteri dari ekstrak biji mengkudu (Morinda citrifolia L.) dan sediaan gel hand sanitizer. Indonesian Journal of Chemical Science 8 (2): 105-110.

Paz, J. E. W., Contrerasb, C. R., Munguíab, A. R., Aguilarc, C. N. dan Inungarayb, M. L. C. (2018). Phenolic content and antibacterial activity of extracts of Hamelia patens obtained by different extraction methods. Brazilian Journal of Microbiology 49: 656661

Pratami, H. A., Apriliana, E. dan Rukmono, P. (2013). Identifikasi mikroorganisme pada tangan tenaga medis dan paramedis di Unit Perinatologi Rumah Sakit Abdul Moeloek Bandar Lampung. Medical Journal of Lampung University 2(5): 85-94

Oktaviana, S., Mursiti, S. dan Wijayati, N. (2019). Uji aktivitas antibakteri dari ekstrak biji mengkudu (Morinda citrifolia L.) dan sediaan gel hand sanitizer. Indonesian Journal of Chemical Science 8 (2): 105-110.

Putri, M.A., Saputra, M. E., Amanah, I. N. dan Fabiani, V. A. (2019). Uji fisik sediaan gel hand sanitizer ekstrak daun pucuk idat (Cratoxylum glaucum). Prosiding Seminar Nasional Penelitian dan Pengabdian pada Masyarakat. Jurusan Kimia, Fakultas Teknik, Universitas Bangka Belitung.

Rowe, R. C., Sheskey, P. J. dan Quinn, M. E. (2009). Handbook of Pharmaceutical Excipient, 6th Edition, Pharmaceutical Press, London. Halaman 110-113.

Sajid, Z. I., Anwar,F., Shabir, G., Rasul, G. dan Alkharfy, K. M. (2012). Antioxidant, antimicrobial properties and phenolics of different solvent extracts from bark, leaves and seeds of Pongamia pinnata (L.) Pierre.

Sjahid, L. R. (2008). Isolasi dan identifikasi flavonoid dari daun dewandaru (Eugenia uniflora L.). Skripsi. Fakultas Farmasi,SurkartaEfendi, R. M. 2019. Skrining aktivitas antibakteri fraksi kelopak bunga Mussaenda frondosa L. 2019. Journal of Pharmaceutical and sciences 2 (1): 38-44.
Saptarini, N. M., Herawati, I. E., Permatasari, U. Y. (2016). Total flavonoids content in acidified extract of flowers and leaves of gardenia (Gardenia jasminoides Ellis). Asian Journal of Pharmaceutical and Clinical Research 9 (1): 213-215.

Sambou, O., Gassama, A., Karé, M., Gambe, D., Rivard, M., Martens, T. dan Lachaise, I. (2017). Antimicrobial anthraquinones and triterpenoid isolated from Morinda geminata DC (Rubiaceae). Mediterranean Journal of Chemistry 6 (5): 191-195

Suriawiria, U. (2005). Mikrobiologi Dasar. Papan Sinar Sinanti, Jakarta. Halaman 10

Suryani, N. C., Permana, D. G. M., Jambe, A. (2016). Pengaruh Jenis Pelarut Terhadap Kandungan Total Flavonoid dan Aktifitas Antioksidan Ekstrak Daun Matoa (Pometia pinnata), Jurnal ITEPA 5 (1): 1-10

Syafril, D. S. N., Astuti, I. Y., dan Suparman, S. (2012). Uji sifat fisis gel antiacne ekstrak daun gambir (Uncaria gambir Roxb) dalam basis Na CMC dan uji aktivitas antibakteri terhadap S. aureus. Pharmacy 9(2): 118-127.

Tilloo, S. K., Bodhankar, M. M., Walkar, S. B. dan Pande, V. B. (2012). International Journal of Advances in Pharmacy Biology and Chemistry 1(2): 172-175.

Toding, S. D. S., Herny., Simbala., Deby., dan Mpila. (2020). Uji daya hambat ekstrak etanol daun kacapiring (Gardenia augusta) terhadap bakteri Staphylococcus aureus, Escherichia coli dan Salmonella thypi. Pharmacon 9 (2): 268-274.

Ukhty, N. (2011). Kandungan senyawa fitokimia, total fenol dan aktivitas antioksidan lamun Syringodium isoetifolium. Departemen Teknologi Hasil Perairan Fakultas Perikanan Dan Ilmu Kelautan Institut Pertanian Bogor.

Warnida, H dan Sukawati, Y. (2016). Formulasi ekstrak daun kokang (Lepisanthes amoena (Hassk.) Leenh.) dalam bentuk gel anti acne. Indonesian Journal on Medical Science 3(2): 75-79

Yagiz, F., Battaloglu, R., S., dan Savran, A. (2017). Antibacterial activity and chemical composition of essential oils from some galium (Rubiaceae) species against pathogenic bacteria. Turkish Journal of Agriculture-Food Science and Technology 5 (11): 1330-1333. 